\title{
Prolificacy in Raighar goats is independent of FecB gene
}

\author{
Tapan Kumar Palai ${ }^{1}$, Purna Chandra Bisoi ${ }^{2}$, Apratim Maity ${ }^{2}$, Prakash Chandra Behera ${ }^{2}$, Gyanaranjan Sahoo ${ }^{2}$, \\ Shamik Polley ${ }^{3}$ and Sachinandan $\mathrm{De}^{3}$
}

1. Indian Veterinary Research Institute, Izatnagar - 243122, Dist. Bareilly (UP) India;

2. College of Veterinary Science, Orissa University of Agriculture and Technology (OUAT), Bhubaneswar, Orissa, India; 3. National Dairy Research Institute (NDRI), Karnal, Haryana, India

Corresponding author: Tapan Kumar Palai, email:tapan.palai@gmail.com

Received: 04-01-2013, Revised: 13-01-2013, Accepted: 19-01-2013, Published online: 10-05-2013

\section{How to cite this article:}

Palai TK, Bisoi PC, Maity A, Behera PC, Sahoo G, Polley S and De S (2013) Prolificacy in Raighar goats is independent of FecB gene, Vet World 6(8): 479-481, doi:10.5455/vetworld.2013.479-481

\begin{abstract}
Aim: The Research was undertaken to find the association between $F e c B$ and high prolificacy in Raighar goats.

Materials and Methods: DNA was extracted from blood, collected from does ( $n=101)$ with history of high prolificacy. Further tetra-primer amplification refractory mutation system (T-ARMS) PCR and agarose gel electrophoresis were followed to screen the mutation.
\end{abstract}

Results: Raighar goats were found to be wild homozygotes suggesting absence of $\mathrm{FecB}$ mutation.

Conclusion: Prolificacy in case of Raighar goats is not due to the mutation at $F e c B$ locus. It is thought to search for other genes or loci in goat fecundity.

Keywords: $F e c B$, mutation, prolificacy, Raighar goat

\section{Introduction}

Goat farming is relatively easy and profitable as goats are well adapted to diverse environments. In commercial farming the benefit is mainly dependent upon the litter size. In mammals, multiple litter size is due to multiple ovulations. Though twinning is common in goats but less frequent is occurrence of quadruplet, quintuplet, and sextuplet kids. As the heritability of litter size is very low, selective breeding as a route will be a slow process for developing the reproductive performance of low prolific goat breeds [1]. In alternative, introduction of a prolificacy gene into nonprolific goat breeds having other desired traits may effectively increase their reproductive performances $[1,2]$.

Genetic mechanism of caprine prolificacy remains to be fully explored [3]. Relationship between ovulation rate and litter size was initially studied in sheep and it was reported that a set of genes were regulating this complex phenomenon known as Fecundity $(\mathrm{Fec})$ genes [4, 5]. Inheritance of twinning and triplet tendency is similar in both sheep and goats [3]. Fec genes belong to transforming growth factor $\beta$ (TGF $\beta$ ) super family [6,7] and among Fec genes $B M P R 1 B$, (Bone morphogenetic protein receptor $1 \mathrm{~B}$, also known as Booroola or FecB or Activin like Kinase 6) present on 6 th chromosome of sheep is the first to be identified contributing towards increase in ovulation rate [8] ensuing greater prolificacy in Merino sheep [4, 9].

The Raigarh Goats are popular meat animals in

This article is an open access article licensed under the terms of the Creative Commons Attribution License (http://creativecommons. org/licenses/by/2.0) which permits unrestricted use, distribution and reproduction in any medium, provided the work is properly cited.
Odisha and are well known for their high prolificacy with frequent twinning and triplet kidding except first kidding which is usually single type.

The aim of current research was to find out the contribution of an established ovine fecundity gene like $F e c B$ towards high prolificacy of Raighar goat by analyzing its polymorphism.

\section{Materials and Methods}

Blood samples $(n=101)$ were collected in sterile vacutainer containing $\mathrm{K}_{3}$-EDTA from Raighar does with history of multiple births over different regions of Nabarangpur district of Odisha as per the guidelines of IAEC (Institutional Animal Ethics Committe) and transported to the laboratory under refrigeration. The genomic DNA was isolated from white blood cells using standard phenol-chloroform protocol [10] and dissolved in TE buffer before storing at $-20^{\circ} \mathrm{C}$ for further use. For detection of $F e c B$ point mutation, Tetra-primer amplification refractory mutation system Polymerase Chain Reaction (T-ARMS-PCR) was followed [7]. Two sets of primers were used; forward outer primer (5'-GTCGCTATGGGGAAGTTTGGA TGGGAA-3'), reverse outer primer (5'-CCCGTCC CT TTGATATCTGCAGCAATG-3'), inner forward primer for A allele (5'-GCTGGTTCC GAGAGACA G AAATATAGCA-3') and inner reverse primer for $G$ allele (5'-ATGTTTTCA TGCCTCAT CAACA CC GA CC-3'). These primers were previously used for investigation of $F e c B$ mutation in Black bengal goat $[9,11]$.

PCR was done with reaction mixture of $50 \mu \mathrm{l}$ containing primers $0.5 \mu \mathrm{l}$ each; Template DNA $2.0 \mu \mathrm{l}$; dNTPs (10mM) $1.0 \mu 1 ; 10 \mathrm{X}$ Taq polymerase buffer 5 $\mu \mathrm{l} ; 25 \mathrm{mM} \mathrm{MgCl}_{2} 3 \mu \mathrm{l}$; Taq DNA polymerase (Promega, USA, 5U/ $\mu 1$ ) $0.5 \mu 1$ and rest volume was 


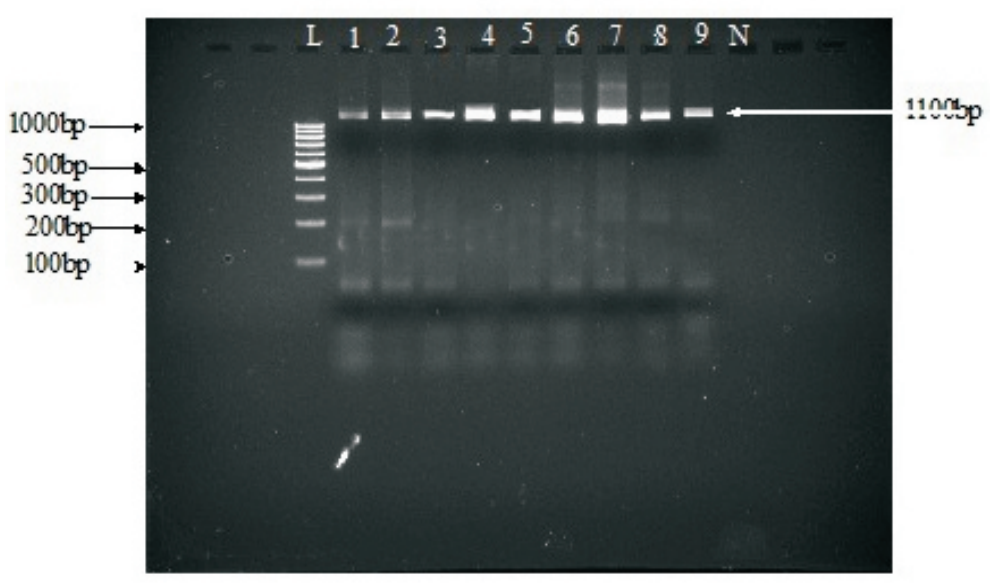

Figure-1. 2\% Agarose gel electrophoresis of allele specific FecB PCR product. Lane; 1-9= Amplification of only wild type (W- $1100 \mathrm{bp}$ product) $\mathrm{L}=$ DNA molecular weight marker (O'RangeRular 100 bp DNA ladder, Fermentus, Lithuania), N= PCR without template/genomic DNA (negative control)

adjusted with nuclease free water. Touchdown cycling conditions were followed for amplification [11]. The PCR amplified product was analysed by $2 \%$ agarose gel along with DNA molecular weight marker.

\section{Results}

Three possible genotypes due to $A$ and $G$ alleles of BMPRIB gene are AA (wild type), GG (Homozygous mutant) and AG (Heterozygous mutant). For screening of genotypes in Raighar goats ( $\mathrm{n}=101), F e c B$ polymorphism was studied through T-ARMS-PCR and electrophoretogram is presented in Fig.1. From the figure it was found that all the tested animals represented amplification of common outer PCR product that was of the amplicon size $1100 \mathrm{bp}$. This product size defined the wild homozygote genotype. There was absolutely no inner band of any product size to describe the mutant genotypes. All goats were found to be wild homozygote suggesting absence of $F e c B$ mutation. Amplicon size of $136 \mathrm{bp}$ would have suggested the presence homozygous mutant genotype whereas; concurrent bands of 1100 and $136 \mathrm{bp}$ proposed genotype of heterozygous mutant type.

\section{Discussion}

The careful regulation of the number of eggs shed and hence the litter size is crucial to successful reproduction in all species of animals [5]. High prolificacy in some sheep breed like Kendrapada of India is due to mutation in $B M P R 1 B$ gene [12]. Number of mutations in $B M P R 1 B$ gene is directly proportional to litter size and ovulation rate $[7,13]$. This increase in ovulation rate of $F e c B$ carriers is associated with a precocious maturation of many of antral follicles that may undergo ovulation with a smaller size $[7,13]$.

In goat breeds there is no such report of $F e c B$ gene being responsible for high prolificacy except in Black bengal goat. Prolificacy in Black bengal is due to $F e c B$ mutation of $B M P R 1 B$ gene [11]. In this context, polymorphism study of $F e c B$ may offer a route to explore the fecundity in Raighar goats as it was the only established ovine fecundity gene responsible for fecundity in one goat breed.

For fecundity gene analysis, restriction fragment length polymorphism [14], allele specific oligonucleotide melting typing [15], primer extension assay [16] and TARMS-PCR [7] are some of the single nucleotide polymorphism (SNP) typing techniques commonly used. T-ARMS-PCR is a simple, rapid and economical method for SNP scoring $[11,17]$ so followed in the current study. It combines the principle of ARMS and the tetra-primer PCR method which can amplify both wild-type and mutant alleles as well as the control fragment in a single-tube PCR reaction [18]. FecB polymorphism studied through T-ARMS PCR reported the monomorphic status of Raighar goat with respect to the gene. FecB mutation was also not observed in Boer, Haimen, Huanyhuai, Nubi and Matou goat breeds having the litter size varied from 1.4 to 2.7 [3]. This suggests there may be some other genes contributing toward caprine fecundity other than BMPR1B. Similarly $\mathrm{Hu}$, the most famous high prolific sheep in China is also wild homozygous for BMPRIB [19]. It validates involvement of different ovine fecundity genes in different sheep breeds viz BMP15 and GDF9 contributing to greater prolificacy in small tailed Han ewes [20] and Brazilian SI sheep [21] respectively.

The prolificacy in Raighar goats may not be due to this established ovine fecundity gene. From above findings it is clear that there may be other genes or loci in goat fecundity. Recent findings suggest the involvement of INHA gene [22] and growth hormone gene [23] in increase litter size in goat-breeds.

\section{Conclusion}

$F e c B$ gene has no affinity for greater prolificacy in Raighar goats of Odisha. The high prolificacy, which was evident from the collected history during the course of sample collection is may be due to some other genes which are yet to be explored or may be due to some other factors.

\section{Authors' contribution}

TKP carried out sample collection, experimental execution, preparation of draft and revision of manuscript. PC Bisoi and SD participated in conception and designing of experiment, trouble shooting and final analysis of result. AM helped in Sample collection and draft preparation, SP assisted in experimental execution and interpretation of findings, 
PC Behera and GS helped in designing of experiment, coordinated the sample collection and revision of manuscript. All authors read and approved the final manuscript.

\section{Acknowledgements}

Authors are thankful to Dean, College of Veterinary Science and A.H., OUAT, Bhubaneswar and Genomic lab, NDRI, Karnal, India for providing the necessary facilities and fund to carry out this work. We acknowledge the cooperation made by veterinary officers and farmers during sample collection.

\section{Competing interests}

Authors declare that they have no competing interest.

\section{References}

1. Pardeshi, V. C., Sainani, M. N., Maddox, J. F., Ghalsasi, P. M., Nimbkark, C. and Gupta, V. S. (2005) Assessing the role of $F e c B$ mutation in productivity of Indian sheep. Curr. Sci., 89(5):887-890.

2. Montgomery, G. W., Penty, J. M., Lord, E. A. and Broom, M. F. (1995) The search for the Booroola (FecB) mutation. $J$. Reprod. Fertil., Suppl., 49: 113-121.

3. Hua, G.H., Chen, S. L., Ai, J.T. and Yang, L.G. (2008) None of the polymorphism of ovine fecundity major genes FecB and FecX was tested in goat. Anim. Reprod. Sci., 108:279286.

4. Davis, G.H., Montgomery, G.W., Allison, A.J., Kelly, R.W. and Bray, A.R. (1982) Segregation of a major gene influencing fecundity in progeny of Booroola sheep. $N Z J$. Agric. Res., 25:525-529.

5. Baird, D.T. and Campbell, B.K. (1998) Follicle selection in sheep with breed differences in ovulation rate. Mol. Cell. Endocrinol., 145: 89-95.

6. Juengel, J.L., Hudson, N.L., Whiting, L. and McNatty, K.P. (2004) Effects of immunization against bone morphogenetic protein 15 and growth differentiation factor 9 on ovulation rate, fertilization, and pregnancy in ewes. Biol. Reprod., 70:557-561

7. Roy, J., Polley, S., De, S., Mukherjee, A., Batabyal, S., Pan, S., Brahma, B., Datta, T.K. and Goswami, S.L. (2011) Polymorphism of fecundity genes (FecB, FecX, and FecG) in the Indian Bonpala sheep. Anim. Biotechnol., 22(3): $151-162$.

8. Souza, C.J., MacDougall, C., Campbell, B.K., McNeilly, A.S. and Baird, D.T. (2001) The Booroola (FecB) phenotype is associated with a mutation in the bone morphogenetic receptor type 1 B(BMPR1B) gene. J. Endocrinol., 169: R1-R6.

9. Polley, S., De, S., Brahma, B., Mukherjee, A., Vinesh, P.V., Batabyal, S., Kaushik, Arora, J.S., Pan, S., Samanta, A.K., Datta, T. K. and Goswami, S. L. (2010) Polymorphism of BMPR1B, BMP15 and GDF9 fecundity genes in prolific Garole. Trop. Anim. Health Prod., 42: 985-993.
10. Sambrook, J. and Russell, D. (2001) Molecular Cloning. A Laboratory Manual. 3rd edition. Cold Spring Harbor NY.

11. Polley, S., De, S., Batabyal, S., Kaushik, R., Yadav, P., Arora, J.S., Chattopadhyay, S., Pan, S., Brahma, B., Datta, T.K. and Goswami, S.L. (2009) Polymorphism of fecundity genes (BMPR1B, BMP15 and GDF9) in the Indian prolific Black Bengal goat. Small Ruminant Research, 85(2): 122-129.

12. Kumar, S., Mishra, A. K., Kolte, A.P., Dash, S.K. and Karim, S.A. (2008) Screening for Booroola (FecB) and Galway (FecXG) mutation in Indian sheep. Small Ruminant Research, 80: 57-61.

13. Fabre, S., Pierre, A., Mulsant, P., Bodin, L., DiPasquale, E., Persani, L., Monget, P. and Monniaux, D. (2006) Regulation of ovulation rate in mammals: contribution of sheep genetic models. Reprod. Biol. Endocrinol., 4:20.

14. Shi, H., Bai, J., Niu, Z., Muniresha, Fen, L. and Jia, B. (2010) Study on candidate gene for fecundity traits in Xingjiang Cele black sheep. Afr. J. Biotechnol., 9(49): 8498-8505.

15. Zhou, H., Byun, S.O., Frampton, C.M., Bickerstaffe, R. and Hickford, J.G. (2008) Lack of association between CAST SNPs and meat tenderness in sheep. Anim. Genet., 39(3): 331-332.

16. Rempel, L. A., Nonneman, D. J., Wise, T. H., Erkens, T., Peelman, L. J. and Rohrer. G. A. (2010) Association analyses of candidate single nucleotide polymorphisms on reproductive traits in swine. J. Anim. Sci., 88:1-15.

17. Ye, S., Dhillon, S., Ke, X., Collins, A. R. and Day, I. N. (2001) An efficient procedure for genotyping single nucleotide polymorphisms. Nucleic Acids Res., 29: e88-98.

18. Newton, C. R., Graham, A., Heptinstall, L. E., Powell, S. J.,Summers, C., Kalsheker, N., Smith, J. G. and Markham, A.F. (1989) Analysis of any point mutation in DNA. The amplification refractory mutation system (ARMS).Nucleic Acids Res., 17:2503-2516.

19. Guan, F., Liu, S. R., Shi, G. Q., Ai, J. T., Mao, D. G. and Yang, L. G. (2006) Polymorphism of FecB gene in nine sheep breeds or strains and its effects on litter size, lamb growth and development. Acta Genet. Sinica, 33:117-124.

20. Zhang, C.S., Geng, L.Y., Du, L.X., Liu, Z., Fu, Z., Feng, M. and Gong, Y. (2011) Polymorphic Study of FecXG, FecGH and FecB Mutations in Four Domestic Sheep Breeds in the Lower Yellow River Valley of China, J.Anim. Vet. Adv., 10: 2198-2201.

21. Silva, B.D., Castro, E.A., Souza, C.J., Paiva, S.R., Sartori, R., Franco, M.M., Azevedo, H.C., Silva, T.A., Vieira, A.M., Neves, J.P. and Melo, E.O. (2011) A new polymorphism in the Growth and Differentiation Factor 9 (GDF9) gene is associated with increased ovulation rate and prolificacy in homozygous sheep. Anim. Genet., 42(1):89-92.

22. Wu, W., Hua, G., Yang, L., Wen, Q., Zhang, C., Zoheir, K.M. and Chen, S. (2009) Association analysis of the INHA gene with litter size in Boer goats. Small Ruminant Research., 82: 139-143.

23. Zhang, C., Liu, Y., Huang, K., Zeng, W., Xu, D., Wen, Q. and Yang, L. (2011) The association of two single nucleotide polymorphisms (SNPs) in growth hormone $(\mathrm{GH})$ gene with litter size and superovulation response in goat-breeds. Genet. Mol. Biol., 34 (1): 49-55. 